\title{
Religious Thoughts through Imagery in Mrs Dalloway
}

\author{
Lika Tian \\ School of Foreign Languages and Culture \\ Yunnan University of Finance and Economics \\ Kunming, China
}

\author{
Hongmin Li \\ International Cooperation \& Exchange Office \\ Yunnan University of Finance and Economics \\ Kunming, China
}

\begin{abstract}
Since Mrs. Dalloway is one of Virginia Woolf's most famous novels; many critics argue that it is due to the use of modern technical innovations, or the employment of brilliant use of time, or the use of a clever shift of the stream of consciousness. However, this essay argues that Mrs Dalloway is significant mainly because the novel explores the traditional religious symbols and values, making people reconsider the traditional Christian values. This essay aims to persuade that the religious imagery of this novel contributes tremendously to construct the author's anti-religious idea, which is the unsuccessful attempt of Christianity to offer solace to people psychologically.
\end{abstract}

Keywords_-imagery; Christianity; events; objects; characters

\section{INTRODUCTION}

Adeline Virginia Woolf born in 1882 in London was an English essayist, novelist, and feminist. She had written three great, innovatory novels in the 1920s and 1930s: The Waves, Mrs Dalloway, To the Lighthouse, which paved the way for her to become a prominent modern novelist. Among them, Mrs Dalloway is the noticeable one. Published on 14 may, 1925, the novel was a created based on two short stories. It illustrates a day of life of heroine Clarissa Dalloway, especially the details of her arrangements of an evening party that she has to host. Distinctly, there are kinds of themes worth pondering in the book, for instance, feminism, bisexuality, mental illness, existential issues as well as time and secular living. Nevertheless, critics commonly emphasize the novelty of Virginia Woolf's art. They argue that the author uses modern technical innovations, an interesting and brilliant use of time as well as a clever shift of the stream of consciousness from one mind to another. They discuss "her dissolution of the traditional limits of plot and character, her attention to minutiae of the mind to apparently insignificant details of the external world." [3] They study "her pulverization of experience into a multitude of fragmentary particles, each without apparent connection to the others, and her dissolution of the usual boundaries between mind and world.” [4] However, this essay argues that Mrs Dalloway is significant primarily due to the fact that the novel explores the author's religious ideas by repeatedly using imageries. It presents traditional religious symbols and values, making people reconsider traditional Christian values. Virginia Woolf thinks that Christianity cannot comfort people either psychologically or physically. It is only a fantasy which keeps people innocent and ignorant. The imagery of the novel suggests that "the central action of the heroine is to find an adequate substitute for Christianity and the sacramental sense of reality," [4] There are altogether three categories of imagery in the novel, respectively relating to imageries of events, objects and characters.

\section{IMAGERIES OF EVENTS}

Two religious imageries of events took place in Mrs Dalloway. One offers to sacrifice to God while another embraces death as a heroic defiance against Christianity.

\section{A. Imageries of Parties}

The first imagery of events finds itself in the parties Mrs Dalloway throws, being the offering to sacrifice. "To establish the kind of communication which would not violate the mystery of the soul is the self-appointed mission of Clarissa Dalloway.” [3] And her parties, for which she is the object of polite scorn or her means of establishing this delicate relationship. She is the "perfect hostess" whose special gift is to unite, to be "composed so for the world only into one center, one diamond, one woman who sat in her drawing-room and made a meeting-point, a radiancy no doubt in some dull lives, a refuge for the lonely to come to, perhaps.” [7] But the parties are more than social gathering; it is crucial to note that they are described quite precisely as “offerings". But suppose Peter says to her, "yes, yes, but your parties - what's the sense of your parties?”. [7] In the book, Mrs Dalloway does not expect anyone to understand the meaning of her parties. They carry meanings. However, they are terribly vague offerings. Even she herself does not know to whom she is offering. It is to combine and to create. Perhaps it is just an offering in the name of offering. But the key message of the party is that it is her gift to everyone.

The precise sense in which her parties are offerings is revealed by her relationship with Septimus. He would offer himself to save mankind, so would Mrs Dalloway, through her parties, offer herself as sacrifice. She is "the woman who was that very night to give a party; of Clarrisa Dalloway; of herself." [7] A party which symbolizes a sacrifice and an offering is like the Mass. Mrs Dalloway is undoubtedly the perfect hostess who offers herself as a victim or a hero in her Mass to restore the integrity of mankind.

\section{B. Suicide of Septimus Warren Smith}

The second event's imagery is the suicide of Septimus Warren Smith, which is meant to be an aboveboard revolt to Christianity. Septimus Warren Smith is a veteran of World War 
I who constantly lives in the shadows of his deceased friend Evans. Reality and imaginations intertwine in his life of agonies. "The complexity of meaning inherent in the religious imagery emerges above all in the characterization of him," [4] who lurks on Clarissa Dalloway's life. Despite the bitter antagonism against religion in Mrs Dalloway’s mind, Septimus is the one who expresses his ideas to the public. In this atheistic, anti-religious novel, Septimus is a Christ figure, suggesting a continuation of the ironic view of religion. In fact, the agony of Septimus is precisely that of Mrs Dalloway's. He yearns for the unity and integrity of existence which would give significance to his life. The struggle is waged especially in the tortured mind of his. Christianity is not the savior which can rescue him from the sufferings of secular life. Therefore, he chooses to commit suicide which is forbidden by Christian doctrines. Nevertheless, committing suicide is true and brave defiance to the contemporary religion. The significance from Mrs Dalloway's thoughts arises: "Death was defiance. Death was an attempt to communicate; people feeling the impossibility of reaching the center which, mystically, evaded them; closeness drew apart; rapture faded, one was alone. There was an embrace in death." [7] Septimus Smith has fulfilled his strategic function in post-First World War England, which is to concentrate on the religious dimensions of the novel.

\section{IMAGERIES OF OBJECTS}

A handful of imageries find themselves in four objects: flowers, colors, vehicle, and an airplane. Various imageries of religion are illustrated in each of them.

\section{A. Imageries of Flowers}

Objects' imageries start from flowers in which Mrs Woolf aims to demonstrate Christianity is like flowers, only a beautiful decoration which could be abandoned at will. Flowers first appear at Miss Pym's flower shop: “There were flowers: delphiniums, sweet peas, bunches of lilac; and carnations, masses of carnations. There were roses; there were irises." [7] Thereafter metaphors of flowers appear many times in the novel. Those flowers are described with religious imageries. In the story, Peter considers Sally as a young, very young unmarried lady. He has seen Sally wearing a red carnation when she walked across Trafalgar Square, which makes her lips red. There is also a detailed description of a garden of rose bushes and giant cauliflowers where they used to walk. He could remember she tore off a rose and started to appreciate the beauty of the cabbage leaves at night of moonlight. Nevertheless, Peter still reckons that he should hold some flowers to celebrate. Roses or orchids? Instead, he was "grasping his red and white roses together (a vast bunch in tissue paper), is the greatest mistake in the world.[7] In another scenario, she, on the other hand, has picked a rose.

Flowers as Christian symbols belong to early religious art forms. They are designed into various forms which are used to represent abstract concepts and ideas. They are religious symbols or images with sacred meanings. When the majority of people were illiterate and printing was yet invented, Christian symbols with ancient traditions and meanings were extremely popular. According to Christians, a red carnation is the symbol of love whereas a violet is symbol of humanity. The iris represents the Virgin Mary when a lily represents the purity and again Virgin Mary. A red rose is symbol of martyrdom while a white one is symbol of purity. Further, five red petals of a rose flower are believed to represent Christ's wounds and his sacrificial blood. Mrs Woolf uses those symbolic flowers to indicate the status of Christianity in people's heart. Although those flowers can be seen and found in people's life every day and everywhere, just like ubiquitous Christ in their hearts, it does not work, nor does God. People just pretend what they believe is true and powerful. In the novel, nevertheless, there are two exceptions which reflect Mrs Woolf's real thoughts about religion.

The first one is Sally. It says Sally has her own way with flowers. She would put all kinds of flowers, for instance, dahlias, hollyhocks, together in an unusual way, cut the flowers off and let them float on the top of water.

Mrs Woolf puts Sally in a position different from others. Her own unique way of appreciating and enjoying flowers is the symbol of an atheist, which is much the same as Mrs Woolf herself. None of the flowers she put together belongs among the Christian flowers.

Another exception is Mrs. Dempster. For Mrs. Dempster, life always has been hard. She considers roses as trash in life. They have nothing to do with eating, drinking, mating and living.

Mrs. Dempster's idea is the true portrayal of Mrs Woolf. In her thought, a rose is a quintessential representation of Christianity. And she thinks there is much more than roses in real life. Mrs Woolf thinks as much. Religion, especially Christianity, cannot provide people with peace of mind or richness in practical life.

\section{B. Imageries of Colors}

Another kind of imagery has to do with color, used to mock the hypocritical side of Christianity. It is also stated with religious significance. There is a paragraph which depicts all kinds of flowers, delphiniums, carnations, arum lilies, irises, lilac glowing in the morning with blue-black sky. "Lords, Ascot, Ranelagh and all the rest of it; wrapped in the soft mesh of the grey-blue morning air, white, violet, red, deep orange; every flower seems to burn by itself, softly, purely in the misty beds; "[7] In this quotation from the story, there are seven different colors, namely grey, blue, black, white, violet, red and orange. This is a kind of color symbolism of Christianity. The colors used to describe the sky and flowers are obviously symbolic. Grey, color of ash, is used to represent repentance or sometimes used during Lent, a period of 40 weekdays starting from Ash Wednesday to Holy Saturday. Blue, color of sky, is symbol of heaven or truth, commonly accepted as a color relating to liturgy. Black is the liturgical color of Good Friday which symbolizes death. Black can also represent sin which leads to death. White is symbol of purity, innocence and holiness, the liturgic color for Easter and Christmas. Violet represents penitence, mourning as well as royalty. Red is the color of blood. Hence, it is the liturgic color for remembrance of martyred saints. On the other hand, it is color of fire. Therefore, it is also used as the liturgic color for Pentecost, the seventh Sunday after Easter. Orange, same as gold, reminds 
people of heaven, God's abode, where God wants people to be with Him when they die. Then Mrs Woolf repeats the three colors to describe different things: "The sparrows fluttering, rising, and falling in jagged fountains were part of the pattern; the white and blue, barred with black branches." [7] What is noticeable is that the author uses "green" to describe Miss Kilman, who is a stubborn extreme religionist : "so insensitive was she, dressed in a green mackintosh coat." [7] Ironically, green evokes a new life and hope. The writer uses reverse adjective to manifest the true character of Miss Kilman, which is a zealous Christian of cruelty and insensitivity. By using the color "green" on a religionist, the author tries to imply that people are somehow distorted by Christianity.

\section{Vehicle's Imagery}

The third imagery of object is the vehicle which embodies the uselessness of religion in secular society. From Mrs Dalloway's encounter with a government vehicle in the early part of the novel emerges one of the central metaphors: "But now mystery had brushed them with her wing; they had heard the voice of authority; the spirit of religion was abroad with her eyes bandaged tight and her lips gaping wide.” [7] After the car is stopped by a policeman and then allowed to proceed when identification is shown, the religious imagery becomes even more specific.

Clarissa knew she had seen something white, circular and magical before. It is also inscribed with a name. "The white, magical, circular disc possessed of religious significance hardly needs the additional notion of 'Whitbread' to be identified with the Host of the Eucharist," [4] or leastwise the sarcastic functional equivalence of it. The role of Christianity in secular world has been undertaken by government. Government often seems to be invested with dominance, efficiency and enigma, which offers a sense of community to the ordinary people. The irony implies without doubt that the government is regarded unworthy to take on responsibilities and obligations abdicated by religion, say Christianity.

\section{Airplane's Imagery}

Soon after the car vanishes, an airplane appears as the fourth object's symbol of mockery for deformity of religion. The airplane is writing an indecipherable message across the sky, "as if destined to cross from West to East on a mission of the great importance which would never be reveled...”[7] The airplane (which, in its West to East flight, significantly reverses the historic course of Christianity) is interpreted as a religious phenomenon by various people. There is an implication here saying Christianity has abandoned its original roots and beliefs and taken a very different course. To Septimus Smith, the airplane heralds the "birth of a new religion." [7] $\mathrm{He}$ is recovered to sanity and is bestowed an oracular insight of unity of the whole world.

To another observer, the airplane was “a symbol of man's soul; of his determination to get outside his body, beyond his house, by means of thought, Einsteins, speculation, methematics, the Medelian theory..." [7] Yet, to the third observer, the airplane is related to that symbol which it supersedes, the cathedral with its altar and cross "the symbol of something which has soared beyond seeking and questioning and knocking of words together and has become all spirit, disembodied, ghostly...” [3] But the new religion symbolized by the airplane is also fraudulent: its "marvelous revelation" is first mysterious, "then insignificant when it is finally decipherable." [4] The message which the airplane is communicating is the word "toffee", "identified with the strange gods of science and technology, with the kind of speculation that has replaced traditional thought," [3] does not offer solacement to mankind: its "mission of the greatest importance" is to provide service to modern economy.

\section{IMAGERIES OF CHARACTERS}

There are altogether two characters who carry visual imageries in the story. One is Miss Kilman. Another is Clarissa Dalloway herself.

\section{A. Miss Kilman}

Characters' imageries begin with Miss Kilman, a negative example of people who are fanatic about Christianity. Miss Kilman majors in history and was terminated employment from school. Being a born-again Christian, she is a devotee of the Goddess Conversion, incessantly bludgeoning others into her convictions: "it being her experience that the religious ecstasy made people callous (so did causes); dulled their feelings, for Miss Kilman would do anything for the Russians, starved herself for the Austrians, but in private inflicted positive torture," [7] Unquestionably, her tyranny extends into all human relationships, which can be vividly seen from the thoughts of Mrs Dalloway. Mrs Dalloway sees Miss Kilman one of the specters who sucks blood in our life. Mrs Dalloway made it very clear that she would probably love Miss Kilman in an upside-down world with black sides everywhere, but she would never love her in this real world.

On the one hand, the writer expresses it is Miss Kilman's ideas which are annoying. On the other hand, she indicates that her doomed failure "in this world", which is same as the fate of Christianity.

\section{B. Clarissa Dalloway}

The next symbolic character who comes to Mrs. Dalloway twice professes her to be an atheist, representing the original anti-religious idea of Mrs Woolf herself. Clarissa Dalloway, the protagonist of the story, is a 51-year-old married woman who is self-conscious about her status in upper class of London.

She thinks that there are no Gods. Even if there were, Gods have been hurting and spoiling human lives. Plus, there is no one to blame. That's probably why she has evolved into an atheist.

Moreover, this high-society woman Mrs Dalloway holds that Christianity is useless in guiding people to do things. One can behave himself or herself by "doing good for the sake of goodness”. It is not what God tells them to do. Then Mrs Dalloway states her opinions about love and religion directly. "Love and religion! thought Clarissa, how detestable, how detestable they are!... The cruelest things in the world.” [7] She is bitter in her denunciation of religion. 
In addition, when going to church, Mrs Dalloway describes people who wear masks of religion vividly. She thinks that religion is only a disguise of people, concealing something which they don't want others see. It just peels off the hypocritical skin of religion "once they removed them, instantly reverent, middle class, English men and women, some of them desirous of seeing the wax works. "[7]

\section{CONCLUSION}

In conclusion, the novel is constructed by stream of consciousness in and out of the characters' minds with an interior perspective. By using miscellaneous religious imageries of events, objects, and characters, Virginia Woolf implicitly but strongly expresses her anti-religious thoughts in Mrs Dalloway, which is "the monumental failure of Christianity to safeguard the unity of man.” [3] The traditional religious representatives repeatedly appeared in the novel give readers the fundamental problem of Mrs Dalloway, which is "the fragmentation of the modern world, the loss of unity within society and within the individual himself." [4] Mrs Woolf tries to remind readers to re-assess the traditional Christian values. Only by a resumption of the sense of reality, Adeline Virginia Woolf claims, "can man regain his integrity and his wholeness.” [3]

\section{ACKNOWLEDGMENT}

I would like to extend my genuine gratitude to those who supported me during the writing of this paper. First and foremost, high tribute should be paid to Professor Luo Hong, for his consistent encouragement and trenchant instruction, without which, the present paper would not have been accomplished. I am indebted to him due to considerable time and effort that he has put into the comments on the draft. His constructive and incisive instructions have made a great contribution to the completion of the paper. Special thanks go to my husband Jesse Schlabach who has given me valuable suggestions and unwavering support through writing. Finally, I am grateful for my family who gives me continuous support mentally.

\section{REFERENCES}

[1] H. Marjorie, Virginia Woolf's Experiments with Consciousness, Time, and Social Values. New York: E. Mellen Press, 2001.

[2] L. Xiaohong, The Critical Mind. Beijing: Modern Education Press, 2008.

[3] M. Eleanor, Virginia Woolf Critical Assessments, ed., vol.1. London: Helm Information Ltd, 1994.

[4] M. Eleanor, Virginia Woolf Critical Assessments. ed., vol.3. London: Helm Information Ltd, 1994.

[5] R. Harvena, Virginia Woolf: The Inward Voyage. Princeton: Princeton University Press, 1970.

[6] S. Liang, Mrs Dalloway. Transl. Shanghai: Shanghai Translation Publishing House, 1988.

[7] W. Virginia, Mrs Dalloway. Ware: Wordsworth Editions Ltd, 1996

[8] Z. Boxiang, A Course Book of English Literature, ed., vol.2. Wuhan: Wuhan University Press, 2005. 